\title{
職業としての計算機操作に伴う疲労の特徵についで 一計算機利用者向け疲労調査票作成のための基礎研究一
}

\author{
水谷政司**, 鈴木 郁***
}

\begin{abstract}
Many studies that address fatigue caused by computer use have been based on laboratory experiment using inexperienced students as subjects. The aim of this study is to obtain findings with which to develop a fatigue questionnaire appropriate for experienced, occupational computer users. Beforehand, the authors carried out preliminary investigation and let you describe a tendency of computation fatigue freely. A survey was conducted of heavy computer users, including clerks, salesmen, data entry specialists, and computer software programmers. Students were also surveyed for the sake of comparison. 45 people who work for computer manufacturing, software developing company, governmental office for documentation and student majoring in engineering were surveyed. They described without restriction what kind of condition, which part of body, and what kind of fatigue was appeared. The personal information such as an occupation, gender, years of occupational experience were asked. The authors conducted a detailed investigation for the purpose of finding concrete evidence that fatigue of computer operation is the cause in this investigation. From the detailed investigation of the questionnaire, 51 questions were selected. The type of job and the company which were investigated were almost with equivalence with preliminary investigation, the participants were a total of 106 people. Personal information was the same as the preliminary investigation and the entry method of subjective evaluation adopted a VAS method to evaluate a position. In analysis of the data adopted factor analysis method. The authors use principal factor method for method of factor extraction by factor analysis, number of factor use factor loading, eigenvalue, inside item of interpretable. From detailed investigation, It was seen progress to be necessary to achieve a demand, The tendency that the escape and a fret lead to fatigue and factor out of self-responsibility not to change as having thought a tendency to lead to fatigue. This tendency already shows the contents, and cannot pick up from a certain questionnaire. The aim of this study is getting basics document to make a fatigue questionnaire for a computer user. Although variation was found in the condition of the workers, the importance of the survey is that its subjects were occupational computer users in an actual working environment, as opposed to students in a laboratory setting and it seems that a concrete characteristic of fatigue in computer operation was examined.
\end{abstract}

本研究の目的は, 職業としての計算機利用者向け疲労調査票を作成するための基礎資料を得ることであ る. そこで, 計算機操作が多い職種への就業者を対象に計算機操作の疲労を明らかにすることを試みた。 事前に予備調査を実施し, コンピュータ操作疲労の傾向を自由に記述させた. 調查者の選択は, 日常的に 計算機操作が多く長い時間利用する就業者とした. 具体的に, 営業販促職, 開発職, 入力専門職, 事務職 である. 比較として学生も調査した. 調査者の企業傾向は, 計算機製造関連企業, 計算機用ソフト開発企 業, 官庁提出書類作成を行う団体と工学系の学生の 45 名である. 質問では, どのような状況のときに, ど こに，どのように疲れを感じるのかについて自由に記述させた。個人に関する情報については職業，性別， 年齢, 経験年数を尋ねた. 予備調査の傾向をもとに, 計算機操作が及ぼすより具体的な疲労特徵を検討す る目的で詳細調査を行った. 詳細調査票は 51 項目の構成とした. 職種別と企業傾向は予備調査とほほ同一 とし, 人員は合計 106 名に拡大し行った。個人に関する情報は予備調査と同様とした. 主観評価の記入方 法は位置を数值化するVAS 方式を採用した. 取得したデー夕処理には因子分析法を採用した. 因子分析で の因子抽出には主因子法を用い, 因子数の絞込みには因子負荷, 固有値, 内部項目の解釈も考慮した因子 数とした. 詳細調查からは, 要求を達成するために必要な進捗により, 逃避や焦りが疲労につながる傾向 や, 思ったように動かないという自己責任外の要因が疲労につながる傾向が示されていた。これらの傾向 は, すでにある調査票からは拾えない内容を示唆している. 本研究では, 職業としての計算機利用者向け

\footnotetext{
* 受付: 2005 年 1 月 27 日 受理 $: 2006$ 年 2 月 23 日

** 法政大学大学院 Graduate School of Hosei Univ.

*** 法政大学 工学部経営工学科

Faculty of Engineering, Hosei Univ.
} 
の疲労調査票を作成するための基礎資料を得ることを目的としている. 調査者の条件やばらつきは認めら れるものの, 実際の職業で計算機操作を多く行っている人を対象とする重要性が改めて確認され, 計算機 操作疲労の具体的な特徵づけができたものと思われる.

(キーワード : 計算機, 計算機操作, 疲労特徵, 職業別, 調査票)

\section{1. はじめに}

我が国の情報通信技術関連の雇用は，全体の就業者が

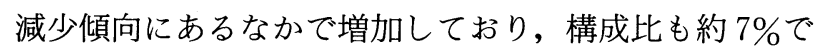
アメリカと比べても遜色ないとの報告 ${ }^{1}$ がある。情報通 信技術関連の就業者では, パーソナルコンピュータを中 心とした各種計算機が多く利用されている。この計算機 は，ハードウェアおよびソフトウェアの技術改良に伴い 情報通信技術関連への普及はもとより，それ以外のさま ざまな職業での利用も知られている.今や企業や個人活 動には必須となった計算機は, VDT 作業拡大などの労 働の変化をもたらし, 使いすぎによる疲労愁訴は情報通 信技術関連に偏らず幅広くの職業からの報告がある。

計算機操作に伴う疲労愁訴は, ドライアイ, 肩こり, 腰痛, ストレスなど多岐に渡り, 疲労愁訴の表現（以下 疲労様態）は操作者おのおのにより違いが見られる。計 算機操作にかかわる疲労の調査, 出版抢よび研究は, 医 学, 心理学, 人間工学など幅広い領域から行われてい る. 計算機操作に伴う疲労からの疾病には, 神経疲労か ら過労性疾患へ進行する例や計算機から離れられないテ クノ依存症への対策の例などを紹介しているさまざまな 文献 ${ }^{2-4)}$ がある. 疲労の研究例には, 植村ら5) による事 象関係電位から抽出された特徵パラメータに基づく精神

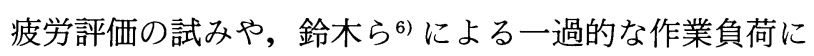
よるストレス評価質問紙の項目と利用方法の検討などが ある。

疲労を調査する方法には，作業の出来高を調査する方 法や，生理指標に基づく方法がある。ただし，これらの 方法は, 一般の企業においての利用例は少なく, 研究例 も学生を被験者とした実験に基づくものが多い. 自覚疲 労調査の方法には, 産業疲労研究会の疲労度調査がよく 知られており, 自覚症しらべ, 作業条件チェックリス 卜, 身体疲労部位調査票の 3 様式による調査方法7) があ る.しかし, この様式は, 計算機操作が中心の職種の疲 労を調查する専用調査票とはいえない。

本研究は, 職業としての計算機利用者向けの疲労調査 票を作成するための基礎資料を得ることを目的としてい る. 計算機操作が多い職種への就業者を対象として, 計 算機操作に伴う疲労に関しての備調査および詳細調査を 行うことにより, 計算機操作が及ぽすより具体的な疲労
の特徴を明らかにする検討を行った。

\section{2. 自覚症予備調査の実施}

疲労様態からの特徵抽出や質問項目を設定するため, 自覚症予備調査を以下の要領で実施した。

\section{2-1. 調査方法と項目の選択}

産業疲労研究会では, 自覚症しらべを 2002 年度に改 定し, 25 項目に分けられた疲労状態に，5段階分けした 訴えのあてはまりを記入し, 疲労の状態を把握する方法 を推奨している. 日本産業衛生学会のVDT 作業研究会 では, VDT 労働チェックマニュアル8)のなかで, OA 機器利用者の健康を守るためのチェックリストを利用し た把握方法を推奨している. 岩崎ら ${ }^{9)}$ の眼精疲労の鑑別 診断用自覚項目でも，多くの疲労特徵を定義している が，いずれの利用例も “5 段階か 7 段階評定記入方法” もしくは“○×式記入方法”が多い.

計算機操作の疲労特徵抽出の検討では, 計算機操作の 多い職種別, 男女別, 年齢別に疲労の特徵を調査するこ とが目的であり, すでにある調査項目の利用では把握が 難しいと考えた，そこで, 操作者が疲労を感じる様子や 訴えを自由に記述させることで疲労様態の傾向と特徵を 調査し，その結果を詳細調査に利用することとした。

\section{2-2. 対象者の選択}

対象者の選定には, 日常的に計算機操作が多い職種に 従事し, かつ, 計算機を長い時間利用する就業者を対象 とした。長い時間とは, 毎日必ず利用し, 計算機なしで は仕事が進まない職種を指している。具体的な分け方と して, 計算機を利用して顧客への提案書や業績資料の作 成などの作業が中心である就業者を “営業販促職”とし て, 計算機用プログラムの設計や作成の作業が中心であ る就業者を “開発職” として，キーパンチャーのような 単純なキーボード操作作業が中心である就業者を “入力 専門職”として, 計算機を利用した売上伝票の作成や仕 入入力, 振替伝票作成などの作業が中心の就業者を “事 務職” として選択した. 比較として, 大学 4 年生, 大学 院生を中心とする “学生”も調查した. 職種別の人数と 計算機操作時の特長を表 1 に示す. 
表 1 予備自覚症調査時の解析対象者属性

Tab. 1 The attributes of the analized subjects in primary reseach.

\begin{tabular}{|c|c|c|c|c|c|c|}
\hline & 就業職種 & 営業販促職 & 開発職 & 入力職専門 & 事務職 & 学生 \\
\hline & 調査対象人員 & 10 & 9 & 9 & 6 & 11 \\
\hline & $\begin{array}{l}\text { 利用するプログラム, 入力など, 操作そのもの } \\
\text { は複雑なのか単純なのか }\end{array}$ & 複雑 & 複雑 & 単純 & 単純 & やや複雑 \\
\hline & $\begin{array}{l}\text { 締切り時間や提出期限の制約などで計算機操作 } \\
\text { が集中することが多い }\end{array}$ & 多い & 多い & 時々多い & 時々多い & 少ない \\
\hline 計 & $\begin{array}{l}\text { 操作作業の内容や成果物が創造的で満足度があ } \\
\text { るがうか } \\
\end{array}$ & ある & ある & ない & ない & 時々ある \\
\hline $\begin{array}{l}\text { 機 } \\
\text { 犁 }\end{array}$ & $\begin{array}{l}\text { 一日の就業時間のなかで, 計算機操作の時間拘 } \\
\text { 束を長く受けている }\end{array}$ & $\begin{array}{c}\text { 多いときも } \\
\text { あり }\end{array}$ & 多い & 多い & $\begin{array}{c}\text { 多いときも } \\
\text { あり }\end{array}$ & 少ない \\
\hline $\begin{array}{l}\text { 時 } \\
\text { の }\end{array}$ & $\begin{array}{l}\text { 職種として計算機を操作している期間が “長期 } \\
\text { に渡る拘束” 受けている } \\
\end{array}$ & いない & いる & いる & いない & いない \\
\hline & $\begin{array}{l}\text { 成果物に対する納期要求がきつい, 品質要求が } \\
\text { 強く求められる }\end{array}$ & 時々ある & 常にある & 常にある & 時々ある & あまりない \\
\hline & $\begin{array}{l}\text { 機器の性能や機器故障が日常作業に大きく影響 } \\
\text { をえる }\end{array}$ & 多い & 多い & 少ない & 少ない & 少ない \\
\hline
\end{tabular}

\section{2-3. 対象者の企業傾向}

調査対象とした企業は, 周辺機器（プリンター, デジ カメ，スキャナなど）メーカーの販売部門，自社ブラン ドの計算機をもつメーカーの計算機本体の販売部門, 企 業向けアプリケーションソフトウェアの製造を行う企 業，計算機用パッケージソフトウェアの開発とユーザー 向けソフトウェアカストマイズを行う企業, 官庁提出用 書類の作成を一括して受託作成を行う団体と工学系の大 学生, 大学院生の合計 45 名とした. 学生を除く 34 名の 年齢分布は, 23 歳から 50 歳まで, 職種経験年数分布 は, 3 年末満から 10 年以上まで, 男女分布は, 男子 19 名に対し女子は 15 名である.

\section{2-4． 調査票の構成と記入方法}

設問は三問に分け記述させた。調査票フォームを図 1 に示す．第一問では，計算機利用時において，どのよう な状況のときに，どこに，どのように疲れを感じるのか について自由に記述させた. 記述から, 具体的な発生時 期, 部位および疲労様態の傾向が抽出可能と考えた。第 二問では, 人間工学研究会の疲労分類法 ${ }^{10)}$ を参考に疲 労を肉体的疲労, 感覚的疲労, メンタルな疲労の区分に 分け, 計算機操作時の疲れた様子についておのおの自由 に記述させた．記述から，愁訴が多い区分と疲労様態の 傾向が抽出可能と考えた。第三問では，VDT 作業によ る一般的な疲労の表現である，肩がこる，目が疲れると いう形容に対し, 調查対象者がこの形容を肉体的疲労, 感覚的疲労, メンタルな疲労のどの区分と認識している のか, その他の形容も含め理由付きで記述させた. 記述 から操作者の疲労認識と疲労区分との関連が把握可能と

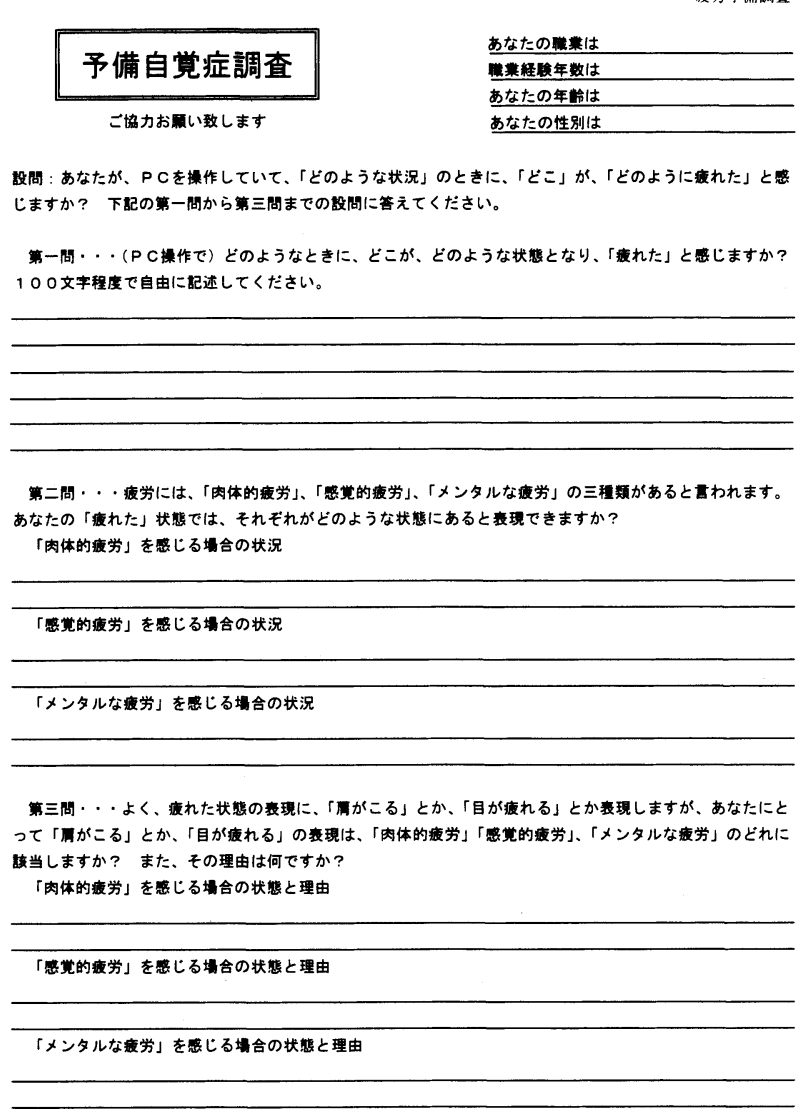

以上、こ協カどうも育り锥うこさいました。

図 1 自覚症調查票（予備調査）

Fig. 1 Questionnaire for the fatigue consciousness (primary research).

考えた. 個人に関する情報については職業, 性別, 年 齢, 経験年数を尋ねた。これらの質問を網羅した調査票 を作成し, 調査対象者に配布し記入させた。また, 記入 の統一性を図るため質問も随時受付けた. 


\section{3. 自覚症予備調査結果}

調査を依頼した 45 名全員から回答を得た，以下に回 答内容の要約を示す.

\section{3-1. 自覚症予備調査票への記入内容}

調査票の第一問における代表的な回答としては，“長 時間，長文を打つとき，単調な作業で肩がこり始めてく る. 定期的に体を伸ばしたりしないとイライラしてくる ようになる.”があった，前半の，(長時間打つ，長文を 打つ，単調な作業により）肩がこるという記述は，(特 定の）肉体部位への疲労様態とした，後半の，(定期的 に体を伸ばしたりしないと）イライラしてくるとの記述 は，メンタル（精神的）な疲労様態とした．代表的な回 答以外の第一問の記述内容も同様に, 肉体的疲労, 感覚 的疲労, メンタルな疲労のいずれかの疲労区分に分類し た。

第二問および第三問では，設問時より，肉体的疲労， 感覚的疲労，メンタルな疲労に区分した記述をさせてお り，各区分への疲労様態の記述をそのまま集計した。そ の後, 第一問から第三問までの, 肉体的疲労, 感覚的疲 労, メンタルな疲労おのおのを集計し, 計算機操作の疲 労様態集計表を作成した。集計表を表 2 に示す。

対象者全体の肉体的疲労には, 目, 肩, 腰などの（特 定の）肉体部位へ表れる疲労様態が多く示された。感覚
的疲労には，ぼんやりやぼやけ感，独り言をいう，ため 息をつくなどの体全身に表れる疲労様態が多く示され た.メンタルな疲労には，フリーズしたときにどっと疲 れる，思ったように動かないとイラつく，根気がなく なってくるなどの心的（メンタル）な疲労様態が多く示 された.

\section{3-2. 自覚症予備調査の傾向と詳細調査の必要性}

疲労の発生に影響する一般的要因には，1）仕事の単 純性（繰返し作業）の程度，2）仕事の量（単位時間あ たりの作業量）の多さ，3）仕事の満足度（創造性や達 成感)，4）仕事の継続度（時間的，期間的拘束)，5）成 果物の納期, 品質要求の強さ，6）計算機応答時間の早 遅や機器故障などがあると考えられる。予備調査から は, 計算機操作の疲労表現が, 操作の長さや集中度によ りいくつかのよく似た疲労にまとまる傾向が示されてい るが, 予備調査では疲労表現の傾向のみであり疲労様態 の程度が調べられているわけではない，予備調査の傾向 をもとに，計算機操作が及ぼすより具体的な疲労特徵を 検討する目的で詳細な自覚症調査を行った。

\section{4. 新たな自覚症調査票による詳細調査}

予備調査で集計した疲労様態を利用した新たな質問票 を作成し，この用紙を用いた詳細な自覚症調査を以下の 要領で実施した。

表 2 予備自覚症調査時の疲労愁訴集計表

Tab. 2 The tally list of fatigue in primary reseach.

\begin{tabular}{|c|c|c|c|}
\hline 肉体的疲労集計 & 感覚的疲労集計 & \multicolumn{2}{|c|}{ メンタルな疲労集計 } \\
\hline 目がつかれる, 乾く & 頭が重い & いらいらしてくる & 閉塞感を感じる \\
\hline 目が乾く & 全身がだるい & 思ったように動かないとイラつく & 考えがまとまらなくなってくる \\
\hline まぶたや筋がぴくぴくする & あくびがでる & 作業の行き詰まり感を感じる & プレッシャーを感じる \\
\hline 視力が落ちる & 全体的な疲労感を感じる & フリーズしたときにどっと疲れる & 作業の中断が気になる \\
\hline 肩がこる, 痛い & 权むくなる & 動作待ち等で遅さを感じ始める & 根気がなくなってくる \\
\hline 腕が痛い & 動作がぎこちなくなる & 画面が眩しく感じる & 切迫感を感じる \\
\hline 指がつる & 横になりたい & 物事に集中できなくなる & きちんとしていられなくなる \\
\hline 背筋が痛い & 頭がぼんやりする & トラブルの発生で疲労度が増す & 目と指のギャップが出てくる \\
\hline 首が凝る & ほんやりする & ミスが多くなり始める & おしまいが見えないと気が重い \\
\hline 腰が痛い & 疲れがたまる & ちょっとしたことが思い出せない & やる気が欠如してくる \\
\hline 頭が痛い & 気分転換したい & 面倒くさくなる & 気が散ってくる \\
\hline 気分が悪い & 体が重たく感じる & 貧乏ゆすりを始める & 操作がイヤになってくる \\
\hline \multirow[t]{4}{*}{ めまいがする } & ため息が出る & 作業にあきてくる & 他人と比較してしまう \\
\hline & だるくなる & 夢に見るようになる & \\
\hline & 独り言をいう & することに間違いが多くなる & \\
\hline & 周囲がぼやけてくる & 行動力が欠如してくる & \\
\hline
\end{tabular}




\section{4-1．詳細な疲労評価の自覚症調査票を新たに作} 成

新たな調査票では, 予備調査票で利用した, 肉体的疲 労, 感覚的疲労, メンタルな疲労の各区分および，おの おのの区分の記述から得られた疲労様態の集計を質問項 目として利用した。詳細な自覚症調查票のフォームを図 2 に，記入方法を 4-4 節に示す.

\section{4-2. 解析対象者の選定と職種別特性}

職種別の区分は予備調查とほぼ同一とした. 予備調査 と詳細な調査との職種別の違いは, 営業の補佐をする営 業事務を事務職に加えたことおよび, 入力指導や入力代 行などを専門に行うインストラクタを入力専門職に加え ている. 職種ごとの調査対象者の作業時間に関しては, 年間を通じての繁忙月，月間を通じての繁忙日，調査対 象者の属性などの違いが見られる。追加した職種もあり 改めて詳細な調査における就業職種別の職務と計算機作 業内容を表 3 に, 調査対象者の属性と平均的な計算機操 作時間を表 4 に示す.

\section{第二回疲学調查}

\begin{tabular}{|c||}
\hline 自覚症調査票 \\
こ協カお耦い致します
\end{tabular}

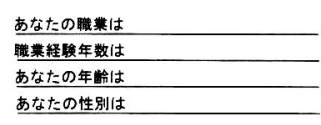

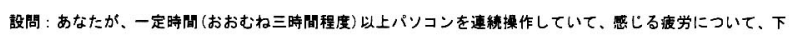
記の第一閣から第三間までの設䦓に答えてください

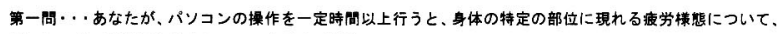
どこに、どの程度現れるかにっいてお答えください。

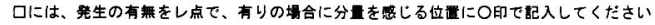

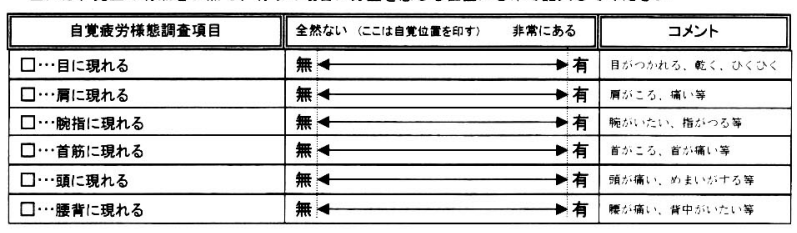

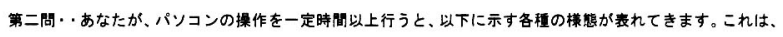
全身的な疲労であるといえます。あなたが忽しる「全身的な疲労」であてはまるものにお荅えください

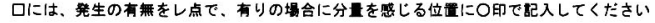

\begin{tabular}{|c|c|c|}
\hline 自賞被学样態調查項目 & 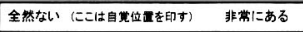 & コメント \\
\hline 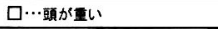 & $\longrightarrow$ 有 & \\
\hline 口・全身がたシるい & $\Longrightarrow$ 有 & \\
\hline ロツあくびかでる & $\longrightarrow$ 有 & \\
\hline 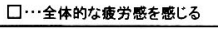 & $\longrightarrow$ 有 & \\
\hline 口“标くなる & $\longrightarrow$ 有 & \\
\hline 口“動作がをこちなくなる & 一有 & \\
\hline 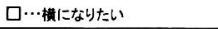 & 無 & \\
\hline ロい碩がほんやりする & $\longrightarrow$ 有 & \\
\hline ロ・ほはんやりする & $\longrightarrow$ 有 & \\
\hline 口・疲れがたまる & $\longrightarrow$ 有 & \\
\hline 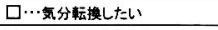 & 無 & \\
\hline ロ体が重たく臨しる & 無 & \\
\hline ロ・だめ息が出る & 無 & \\
\hline 口・だるくなる & 無 & \\
\hline ロ・独りもをいう & 無 & \\
\hline 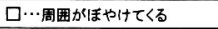 & 無ム & \\
\hline
\end{tabular}

図 2 自覚症調査票（詳細調査）

Fig. 2 Questionnaire for the fatigue consciousness (detailed research).

\section{4-3. 調査対象者の企業傾向}

IT 関連サービスを手がけ，ITソリューションの販売 やサポートを行う企業を 1 社追加した。 それ以外は予備 調査の企業と同一である.

\section{4-4． 詳細な調査票の構成および記入方法}

予備調査では, 肉体的疲労, 感覚的疲労, メンタルな 疲労に分けてそれぞれに自由な記述をさせていた。表 2 のとおり，肉体的疲労に集計された疲労様態のほとんど は，特定の肉体部位を示す内容であった．詳細な自覚症 調査票では，目がつかれる，目が乾く，視力が落ちる， を目に表れるに統合し，肩がこる，肩が痛いは，肩に表 れるに，腕が痛い，指がつるは，腕指に表れるに統合し た。その結果，第一問では，目，肩，腕指，首筋，頭， 腰背など（特定の）肉体部位に表れる疲労として 6 項目 に集約された，第二問では，表 2 のと㧍り，感覚的疲労 に集計された，頭が重い，全身がだるい，全体的な疲労 感を感じるなどの表現を，体全身に表れる疲労として 16 項目すべてを利用した。第三問では，表 2 のとおり，

第二回疲労調查

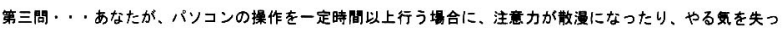
て来たりする事があると思います。これは、心的度労の現われといわれています。あなたが感しるて的度学」 でついてお答えください。

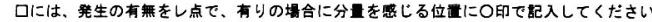

\begin{tabular}{|c|c|c|}
\hline 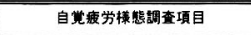 & 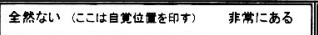 & コメント \\
\hline ロ・いらいらしてくる & $\longrightarrow$ 有 & \\
\hline ロい思ったように二動かないとイラつく & $\longrightarrow$ 有 & \\
\hline 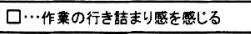 & 無 & \\
\hline ロ・フリーズしたときににどっと疲れる & $\longrightarrow$ 有 & \\
\hline 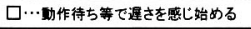 & $\longrightarrow$ 有 & \\
\hline ロ・画面が㫢しく感しる & $\longrightarrow$ 有 & \\
\hline ロ・物事に集中できなくなる & $\longrightarrow$ 有 & \\
\hline ロ・トラフルの在生で摭労度が增す & $\longrightarrow$ 有 & \\
\hline 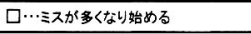 & $\longrightarrow$ 有 & \\
\hline ロ・少よっとした事が思い出せない & $\longrightarrow$ 無 & \\
\hline 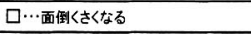 & $\longrightarrow$ 有 & \\
\hline ロ・實乏中すりを始める & $\longrightarrow$ 有 & \\
\hline 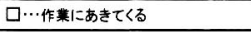 & 無 & \\
\hline 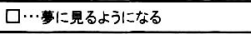 & 無 & \\
\hline ロツすするととに間橾いが多くなる & $\longrightarrow$ 有 & \\
\hline$\square \cdots$ 行助力が久如してくる & $\longrightarrow$ 有 & \\
\hline 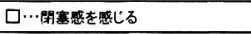 & 無 & \\
\hline 口“考えがままららなくなってくる & 無 & \\
\hline ロ・・゙レッシャーーを感しる & $\longrightarrow$ 有 & \\
\hline 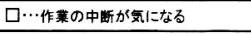 & 無 & \\
\hline 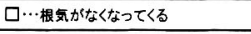 & $\longrightarrow$ 有 & \\
\hline 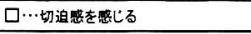 & $\longrightarrow$ 有 & \\
\hline ロいききちんとしていられなくなる & 無 & \\
\hline 口・目と指のギャクフが出てくる & 無 & \\
\hline 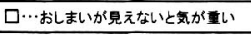 & 無৬ $\longrightarrow$ 有 & \\
\hline 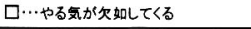 & 無 & \\
\hline 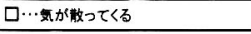 & 無 $\longrightarrow$ 有 & \\
\hline ロ・操作がイヤになってくる & 無 $\longrightarrow$ 有 & \\
\hline ロ‥他人との比較してしまう & 無 & \\
\hline
\end{tabular}


表 3 詳細な自覚症調查時の解析対象者属性

Tab. 3 The attributes of the analized subjects in detailed reseach.

\begin{tabular}{|c|c|c|c|c|c|c|}
\hline & 就業職種 & 営業販促職 & 開発職 & 入力専門職 & 事務職 & 学生 \\
\hline \multirow[b]{3}{*}{$\begin{array}{l}\text { 調 } \\
\text { 查 } \\
\text { 人 } \\
\text { 員 } \\
\text { 所 } \\
\text { 属 } \\
\text { と } \\
\text { 職 } \\
\text { 務 } \\
\text { 容 }\end{array}$} & 人員 & 26 名 & 25 名 & 21 名 & 11 名 & 23 名 \\
\hline & 所属 & $\begin{array}{l}\text { 営業, 企画, マーケティ } \\
\text { ング }\end{array}$ & 開発，SE，プログラマ & $\begin{array}{l}\text { キーパンチャー, インス } \\
\text { トラクター }\end{array}$ & 一般事務職，営業事務職 & 大学, 大学院生 \\
\hline & 仕事の概要 & $\begin{array}{l}\text { 計算機本体と周辺機器の } \\
\text { 営業, 販売促進, マーケ } \\
\text { ティングに従事する職種 } \\
\text { で, 仕事内容は, 提案書 } \\
\text { や企画書の作成, 顧客管 } \\
\text { 理や統計データの作成な } \\
\text { どが計算機操作内容であ } \\
\text { る. 比較的, 男性比率が } \\
\text { 高い職種である. }\end{array}$ & $\begin{array}{l}\text { 計算機を使って, 計算機 } \\
\text { 用のプログラム作成に従 } \\
\text { 事する職種で, 作成プロ } \\
\text { グラムは, 業務用, 汎用 } \\
\text { アプリケーション用, } \\
\text { WEB 関連用などに渡っ } \\
\text { ている. 比較的, 男性の } \\
\text { 比率が高い職種である. }\end{array}$ & $\begin{array}{l}\text { 入力原票の入力項目を参 } \\
\text { 照し, 計算機の専用画面 } \\
\text { の入力項目に従い単純に } \\
\text { データ入力を行うキーパ } \\
\text { ンチャーと入力指導や入 } \\
\text { 力代行などのオペレーシ } \\
\text { ヨンに従事する職種であ } \\
\text { る. 女性の比率が高い職 } \\
\text { 種である. }\end{array}$ & $\begin{array}{l}\text { 一般的な事務職と, 営業 } \\
\text { に代わって計算機で見積 } \\
\text { 書の作成, 提案書の清 } \\
\text { 書, 提案資料の検索など } \\
\text { の補助的な仕事に従事す } \\
\text { る営業事務職を事務職と } \\
\text { した. 女性の比率が比較 } \\
\text { 的高い職種である. }\end{array}$ & $\begin{array}{l}\text { 学部や学科, 個人の趣味 } \\
\text { などで操作の量や時間が } \\
\text { 大きく分かれる傾向があ } \\
\text { る. 左に提示の職種就業 } \\
\text { 者に比較すると操作は少 } \\
\text { ない. 今回調査は工学部 } \\
\text { 系で比較的計算機を利用 } \\
\text { している学生を対象とし } \\
\text { ている. }\end{array}$ \\
\hline \multirow{8}{*}{$\begin{array}{c}\text { 計 } \\
\text { 算 } \\
\text { 利 } \\
\text { 第 } \\
\text { 時 } \\
\text { の }\end{array}$} & 仕事の単純性 & 複雑 & 複雑 & 単純 & 単純 & やや複雑 \\
\hline & 仕事の量 & 多い & 多い & 時々多い & 時々多い & 少ない \\
\hline & 仕事の満足度 & ある & ある & ない & ない & 時々ある \\
\hline & 時間的継続性 & 多いときもあり & 多い & 多い & 多いときもあり & 少ない \\
\hline & 期間的継続性 & ない & ある & ある & ない & ない \\
\hline & 納期要求 & 時々ある & 常にある & 常にある & 時々ある & あまりない \\
\hline & 品質要求 & 時々ある & 常にある & 常にある & 時々ある & あまりない \\
\hline & 性能要求 & 多い & 多い & 少ない & 少ない & 少ない \\
\hline \multirow{3}{*}{$\begin{array}{l}\text { 調 } \\
\text { 查 } \\
\text { 者 } \\
\text { 平 } \\
\text { 均 }\end{array}$} & $\begin{array}{c}\text { (年間を通じて) } \\
\text { 繁忙月 } \\
\end{array}$ & $\begin{array}{l}\text { イベント実施月（6，10, } \\
11 \text { 月，決算月，期末需 } \\
\text { 要月（3 月 }\end{array}$ & $\begin{array}{l}\text { プログラム, システムの } \\
\text { 納品月前 } 1 \text { ケ } 2 \text { ケ }\end{array}$ & $\begin{array}{l}\text { 期末需要期 (3月)，ボ } \\
\text { ーナス支給月 (6，7，12 } \\
\text { 月） }\end{array}$ & $\begin{array}{l}\text { イベント実施月（6，10, } \\
11 \text { 月)，決算月，期末需 } \\
\text { 要月（3 月 })\end{array}$ & $\begin{array}{l}\text { テスト時, レポート提出 } \\
\text { 時 }\end{array}$ \\
\hline & $\begin{array}{c}\text { (月間を通じて) } \\
\text { 繁忙日 }\end{array}$ & $\begin{array}{l}\text { 月末（予算の締切り）と } \\
\text { 月初（前月データ作成） }\end{array}$ & $\begin{array}{l}\text { プログラム, システムの } \\
\text { 納品月前 } 1 \text { ケ月 }\end{array}$ & $\begin{array}{l}\text { 毎月 } 20 \text { 日過ぎから月末 } \\
\text { まで, 特に月末 } 4 \text { 日間 }\end{array}$ & $\begin{array}{l}5,10, \text { 支払い日前と月 } \\
\text { 末, 月初 (請求書発行と } \\
\text { 月次デー夕作成) }\end{array}$ & 不明 \\
\hline & $\begin{array}{c}\text { (年間を通じて) } \\
\text { 閑散月 }\end{array}$ & 平均的に 1 月, 2 月, 8 月 & $\begin{array}{l}\text { プログラム, システムの } \\
\text { 納品月後 } 1 \text { ケ月 }\end{array}$ & 平均的に 1 月, 2 月, 8 月 & 平均的に 1 月, 2 月, 8 月 & 不明 \\
\hline
\end{tabular}

表 4 解析対象者属性分布

Tab. 4 The attributes of the analized subjects.

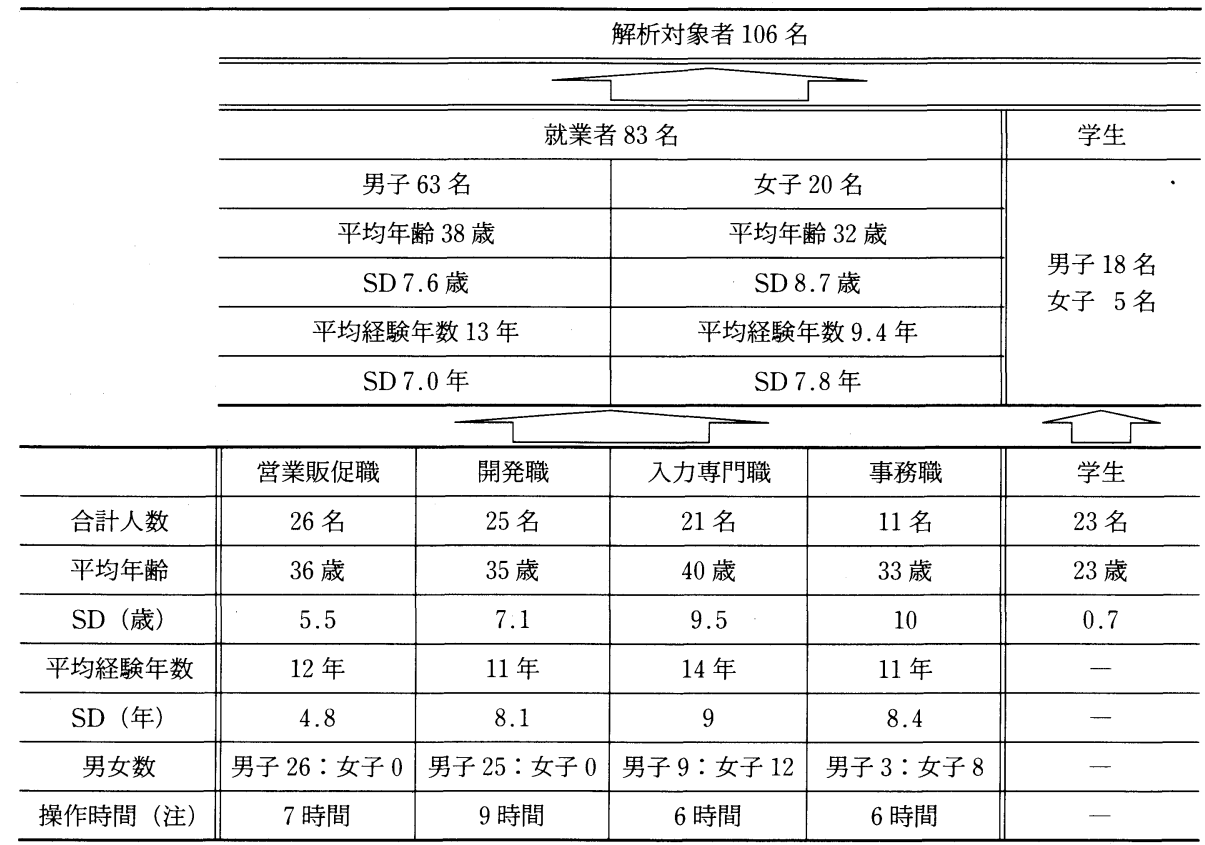

注）表 3 繁忙日における平均計算機作業從事時間 
メンタルな疲労に集計された, いらいらしてくる, 思っ たように動かないといらつく, 作業の行き詰まり感を感 じるなどの表現を，心的（メンタル）な疲労として 29 項目すべてを利用した．新しく作成した詳細な調査票で は，第一問から第三問までの 3 区分，質問項目が合計で 51 項目の構成となった。個人に関する情報については 予備調査と同様に, 職業, 性別, 年齢, 経験年数を尋的 た. 主観評価を自覚症調査票に記入する方法は, $\bigcirc \times$ 式 や段階評価式の採用を考えたがこの方法では主観の強さ を正確に数值化できない. 問題解決の方法として, 鈴木 $ら^{6)}$ と同様に主観評価の分量を，“ない”から“ある” が両端に記入のある線分上のあてはまるところに印を入 れ, 位置を数值化するVAS（ビジュアルアナログス ケール）方式を採用した。 また, 記入者の記入上の負担 を考慮して発生のあり, なしのチェックボックスも設け た.

これら内容を網羅した調查票を作成し, 対象者に配布 し記入させた。記入の統一性を図るため質問も随時受付 けた。

\section{5. データ処理}

職種別, 男女別, 年齢別, 経験年数別などの属性内容 を含めて取得した 5,406 件（106 名 $\times 51$ 項目）のデー夕 の分析処理には, 疲労様態を少数の潜在因子として捕ら える因子分析法を採用した。 因子分析は, 構造モデルの 仮説検証や推定, 多次元デー夕の集約に用いられる手法 で, 集約された因子をスケールとし, 変数や個体の類似 性やポジショニングを明らかにする ${ }^{11,12)}$ といわれてい る.

因子分析での因子抽出には主因子法を用いた. 因子累 積寄与率 70\%以上を重視すると 16 因子と多くの因子が 抽出された. 菅ら ${ }^{13)}$ による 50 程度の変数では 8 因子 程度が妥当で, 設問が多い場合および内容が複雑な場合 に因子数が多くなる傾向があり, 累積因子負荷量と因子 集約数が一致しないことが多いとしている. 疲労特徵の 潜在因子把握のための因子数の絞込み, 決定には因子負 荷が 0.4 以上, 固有值 1 以上の基準を設け, バリマック ス回転後, スクリープロットおよび因子分析による内部 項目の解釈も考慮した因子数を抽出した. 因子分析のま とめ方は, 西川ら ${ }^{14)}$ や加藤ら ${ }^{15)}$ と同様に抽出因子の疲 労样態を特徵化し, 解析対象者の因子負荷量をイメージ マップとして示す方法を用いた。

\section{6. 結 果}

因子分析は，106 名，51 項目の質問に対して職種別な ぞの属性別と, 設問（第一問から第三問まで） 3 区分別 に行った. 結果を以下に示す.

\section{6-1. 疲労様態 51 項目の因子分析結果}

学生を含む解析対象者 106 名全体を対象とした計算機 操作疲労では, 5 因子を抽出した. 抽出因子の負荷量最 上位に表れた項目の様態は, 表 5 に示すように, 第 1 因 子では“面倒くさくなる”，第 2 因子では“ちょっとし たことが思い出せない”，第 3 因子では“独り言をい う”，第 4 因子では“思ったように動かないとイラつ く”，第 5 因子では “肩に表れる”であった。なお，表 中に記載の因子の特徴名については, 考察にて述べる.

学生を除く就業者 83 名を対象に職種別に分け, それ ぞれの職種ごとに 3 因子を抽出した。各職種ごとの第 1 因子の負荷量最上位に表れた項目の様態は表 6 亿示すよ うに, 営業販促職（26名）では“考えがまとまらなく なってくる”, 開発職（25名）では“体が重く感じる”, 入力専門職（21 名）では“プレッシャーを感じる”, 事 務職（11名）では“作業の行き詰まり感”であった. なお, 比較としての学生（23名）では“操作がイヤに なってくる”であった.

学生を除く就業者 83 名を対象に男女別に分け, 男女 ごとに 3 因子を抽出した. 男女ごと第 1 因子の負荷量最 上位に表れた項目の様態は表 7 に示すように, 男子(63 名）では“ほんやりする”，女子（20名）では“行動力

表 5 計算機操作疲労全体の因子分析結果

Tab. 5 Result of factor anaysis related to the characteristics of fatigue by PC operation.

\begin{tabular}{|c|c|c|c|}
\hline 因子 & 特徵名 & 疲労様態 & 負荷量 \\
\hline 1 & $\begin{array}{l}\text { 意欲の低下を } \\
\text { 表す特徵 }\end{array}$ & $\begin{array}{l}\text { 面倒くさくなる } \\
\text { 行動力が欠如してくる } \\
\text { 作業にあきてくる } \\
\text { 全体的な疲労感 } \\
\text { 体が重く感じる } \\
\text { だるくなる }\end{array}$ & $\begin{array}{l}0.614 \\
0.604 \\
0.602 \\
0.601 \\
0.580 \\
0.516 \\
\end{array}$ \\
\hline 2 & $\begin{array}{l}\text { 焦燥感を表す } \\
\text { 特徵 }\end{array}$ & $\begin{array}{l}\text { ちょっとしたことが思い出せない } \\
\text { 切迫感を感じる } \\
\text { 周囲がぼやける }\end{array}$ & $\begin{array}{l}0.623 \\
0.581 \\
0.564 \\
\end{array}$ \\
\hline 3 & $\begin{array}{l}\text { 不安定感を表 } \\
\text { す特徵 }\end{array}$ & $\begin{array}{l}\text { 独り言をいう } \\
\text { 物事に集中できなくなる }\end{array}$ & $\begin{array}{l}0.689 \\
0.541 \\
\end{array}$ \\
\hline 4 & $\begin{array}{l}\text { 自己責任外を } \\
\text { 表す特徵 }\end{array}$ & $\begin{array}{l}\text { 思ったように動かないとイラつく } \\
\text { フリーズしたときにどっと疲れる } \\
\text { いらいらしてくる }\end{array}$ & $\begin{array}{l}0.598 \\
0.567 \\
0.560 \\
\end{array}$ \\
\hline 5 & $\begin{array}{l}\text { 身体的不調を } \\
\text { 表す特徵 }\end{array}$ & $\begin{array}{l}\text { 肩に表れる } \\
\text { 疲れがたまる } \\
\text { 首筋に表れる }\end{array}$ & $\begin{array}{l}0.620 \\
0.615 \\
0.538\end{array}$ \\
\hline
\end{tabular}

原著・職業としての計算機操作に伴う疲労の特徵について 
表 6 計算機操作疲労特徵の因子分析結果（職業別, 第一 因子，上位 6 項目）

Tab. 6 Results of factor analysis of fatigue caused by PC operation (occupation, factor 1 , higher 6 items).

\begin{tabular}{|c|c|c|c|c|}
\hline $\begin{array}{l}\text { 就業 } \\
\text { 職種 }\end{array}$ & 人数 & 特徵名 & 疲労様態（第一因子） & 負荷量 \\
\hline $\begin{array}{l}\text { 営業 } \\
\text { 販促職 }\end{array}$ & 26 名 & $\begin{array}{l}\text { 集中力の欠 } \\
\text { 如を表す } \\
\text { 特徵 }\end{array}$ & $\begin{array}{l}\text { 考えがまとまらなくなってくる } \\
\text { 気が散ってくる } \\
\text { 疲れがたまる } \\
\text { 横になりたい } \\
\text { ぼんやりする } \\
\text { 物事に集中できなくなる } \\
\end{array}$ & $\begin{array}{l}0.760 \\
0.734 \\
0.727 \\
0.717 \\
0.687 \\
0.655\end{array}$ \\
\hline 開発職 & 25 名 & $\begin{array}{l}\text { 意欲興味の } \\
\text { 喪失を表す } \\
\text { 特徵 }\end{array}$ & $\begin{array}{l}\text { 体が重く感じる } \\
\text { 他人と比較してしまう } \\
\text { 全体的な疲労感 } \\
\text { やる気が欠如してくる } \\
\text { ため息が出る } \\
\text { 作業にあきてくる }\end{array}$ & $\begin{array}{l}0.808 \\
0.791 \\
0.752 \\
0.745 \\
0.735 \\
0.710 \\
\end{array}$ \\
\hline $\begin{array}{l}\text { 入力 } \\
\text { 専門職 }\end{array}$ & 21 名 & $\begin{array}{l}\text { 倦㤐意識を } \\
\text { 表す特徵 }\end{array}$ & $\begin{array}{l}\text { プレッシャーを感じる } \\
\text { 操作がイヤになってくる } \\
\text { だるくなる } \\
\text { 考えがまとまらなくなってくる } \\
\text { 作業の行き詰まり感 } \\
\text { 気が散ってくる }\end{array}$ & $\begin{array}{l}0.991 \\
0.991 \\
0.934 \\
0.863 \\
0.817 \\
0.704 \\
\end{array}$ \\
\hline 事務職 & 11 名 & $\begin{array}{l}\text { 危機感危険 } \\
\text { 感を表す } \\
\text { 特徵 }\end{array}$ & $\begin{array}{l}\text { 作業の行き詰まり感 } \\
\text { プレッシャーを感じる } \\
\text { 目と指のギャップが出てくる } \\
\text { 行動力が欠如してくる } \\
\text { 作業の中断が気になる } \\
\text { 夢に見るようになる }\end{array}$ & $\begin{array}{l}0.905 \\
0.873 \\
0.844 \\
0.844 \\
0.844 \\
0.844 \\
\end{array}$ \\
\hline 学生 & 23 名 & $\begin{array}{l}\text { 作業意欲の } \\
\text { 低下を表す } \\
\text { 特徵 }\end{array}$ & $\begin{array}{l}\text { 操作がイヤになってくる } \\
\text { 切迫感を感じる } \\
\text { 根気がなくなってくる } \\
\text { 閉塞感を感じる } \\
\text { いらいらしてくる } \\
\text { 首筋に表れる症状 }\end{array}$ & $\begin{array}{l}0.884 \\
0.736 \\
0.717 \\
0.706 \\
0.686 \\
0.680\end{array}$ \\
\hline
\end{tabular}

表 7 計算機操作疲労特徵の因子分析結果（男女別，第一 因子, 上位 5 項目)

Tab. 7 Results of factor analysis of fatigue caused by PC operation (male and female, factor 1 , highr 5 items).

\begin{tabular}{|c|c|c|c|c|c|}
\hline & 人数 & 特徵名 & 疲労様態（第一因子） & 負荷量 \\
\hline \multirow{2}{*}{$\begin{array}{l}\text { 男 } \\
\text { 各 }\end{array}$} & 男子 & 63 名 & $\begin{array}{l}\text { 作業意欲低下を } \\
\text { 表す特徴 } \\
\text { (表現は間接的) }\end{array}$ & $\begin{array}{l}\text { ほんやりする } \\
\text { ため息が出る } \\
\text { 作業の行き詰まり感 } \\
\text { 周囲がぼやける } \\
\text { 切迫感を感じる }\end{array}$ & $\begin{array}{l}0.701 \\
0.645 \\
0.636 \\
0.634 \\
0.622\end{array}$ \\
\hline & 女子 & 20 名 & $\begin{array}{l}\text { 作業能率低下を } \\
\text { 表す特徵 } \\
\text { (表現は直接的) }\end{array}$ & $\begin{array}{l}\text { 行動力が欠如してくる } \\
\text { 作業の行き詰まり感 } \\
\text { 目と指のギャップが出てくる } \\
\text { プレッシャーを感じる } \\
\text { 画面が眩しく感じる }\end{array}$ & $\begin{array}{l}0.933 \\
0.933 \\
0.933 \\
0.892 \\
0.757\end{array}$ \\
\hline
\end{tabular}

が欠如してくる”であった。

学生を除く就業者 83 名を対象に 35 歳以下と 36 歳以 上の年齢層に分け，年齢層ごとに，おのおの 3 因子を抽 出した. 年齢層を 35 歳とした理由は, 計算機利用者全 般ではないが, SE やプログラマという開発職において 35 歳定年説 ${ }^{16)}$ が言われているためである. 年齢層ごと
表 8 計算機操疲労特徴の因子分析結果 (年齢層別, 第一 因子, 上位 5 項目)

Tab. 8 Results of factor analysis of fatigue caused by operating PC (age, higher 5 items).

\begin{tabular}{|c|c|c|c|c|c|}
\hline & 人数 & 特徵名 & 疲労（第一因子） & 負荷量 \\
\hline \multirow{2}{*}{$\begin{array}{l}\text { 年 } \\
\text { 齢 } \\
\text { 層 } \\
\text { 別 }\end{array}$} & $\begin{array}{l}35 \text { 歳 } \\
\text { 以下 }\end{array}$ & 38 名 & $\begin{array}{l}\text { 切迫感と焦りを } \\
\text { 表す特徵 }\end{array}$ & $\begin{array}{l}\text { 気が散ってくる } \\
\text { 疲れがたまる } \\
\text { やる気が欠如してくる } \\
\text { トラブルの発生で度労度が増す } \\
\text { いらいらしてくる }\end{array}$ & $\begin{array}{l}0.770 \\
0.661 \\
0.645 \\
0.629 \\
0.583\end{array}$ \\
\hline & $\begin{array}{l}36 \text { 歳 } \\
\text { 以上 }\end{array}$ & 45 名 & $\begin{array}{l}\text { 倦怠感の進行を } \\
\text { 表す特徵 }\end{array}$ & $\begin{array}{l}\text { 全体的な疲労感 } \\
\text { 面倒くさくなる } \\
\text { 全身がだるい } \\
\text { 体が重く感じる } \\
\text { だるくなる }\end{array}$ & $\begin{array}{l}0.667 \\
0.651 \\
0.649 \\
0.619 \\
0.602\end{array}$ \\
\hline
\end{tabular}

の第 1 因子の負荷量最上位に表れた項目の様態は表 8 に 示すように, 35 歳以下（38名）では“気が散ってく る”，36 歳以上（45 名）では“全体的な疲労感”であっ た。

\section{6-2. 設問（第一問から第三問まで）3区分おの おのの因子分析結果}

詳細調查時に質問を分けて記入させた，(特定の）肉 体部位に表れる疲労, 体全身に表れる疲労, 心的（メン タル）な表れの疲労それぞれの疲労にはどのような因子 が潜んでいるか, 各区分の項目数を考慮し，おのおの 2 因子ずつ抽出した。第 1 因子の負荷量最上位に表れた項 目の様態は表 9 に示すように，（特定の）肉体部位に表 れる疲労（疲労様態 6 項目）では “首筋に表れる”，体 全身に表れる疲労（疲労様態 16 項目）では“体が重く 感じる”, 心的 (メンタル) な表れの疲労（疲労様態 29 項目）では“やる気が欠如してくる”であった。

因子分析における因子得点は, 解析対象者の観測変数 として，因子影響を示す17) といわれている。(特定の) 肉体部位に表れる疲労マップでは図 3 (a)に示すように, マップの 0 近辺に得点者の全体が一様に分布する傾向を 示している. 体全身に表れる疲労マップでは図 $3(\mathrm{~b})$ に示 すように, マップの 0 近辺に得点者の多くが一様に分布 しているが, 0 近辺から右, 上方向にも得点者が分散し た分布が見られる.心的（メンタルな）疲労マップでは 図 3 (c)に示すように, 解析対象者全体の得点分布が全体 としてバラバラな分布の傾向を示している.ちなみに， いずれの図においても強い相関 $(r>0.7)$ は認められ なかった.

\section{7. 考 察}

自覚症しらべでは，肩がこる，全身がだるい，考えが 
表 9 疲労様態と因子分析結果

Tab. 9 Result of characteristics fatigue subjects and factor analysis.

\begin{tabular}{|c|c|c|c|c|c|c|}
\hline \multicolumn{7}{|c|}{ 疲労様態全体（51 項目） } \\
\hline & \multicolumn{2}{|c|}{$\begin{array}{c}\text { (特定の) 肉体部位に表れる } \\
\text { 疲労様態 }(6 \text { 項目) }\end{array}$} & \multicolumn{2}{|c|}{$\begin{array}{c}\text { 体全身に表れる } \\
\text { 疲労様態（16 項目） }\end{array}$} & \multicolumn{2}{|l|}{$\begin{array}{c}\text { 心的（メンタル）に表れる } \\
\text { 疲労樣態 (29 項目) }\end{array}$} \\
\hline \multirow[b]{2}{*}{$\begin{array}{c}\text { 因 } \\
\text { 子 } \\
1\end{array}$} & \multicolumn{2}{|c|}{ I 首肩に表れる特徵 } & \multicolumn{2}{|c|}{ I だるさ感を表す特徵 } & \multicolumn{2}{|l|}{ I 作業意欲の低下を表す特徵 } \\
\hline & $\begin{array}{l}\text { 首筋に表れる } \\
\text { 肩に表れる }\end{array}$ & $\begin{array}{l}0.738 \\
0.583\end{array}$ & $\begin{array}{l}\text { 体が重く感じる } \\
\text { 全体的な疲労感 } \\
\text { 全身がだるい } \\
\text { だるくなる }\end{array}$ & $\begin{array}{l}0.680 \\
0.620 \\
0.587 \\
0.517\end{array}$ & $\begin{array}{l}\text { やる気が欠如してくる } \\
\text { 作業にあきてくる } \\
\text { 気が散ってくる } \\
\text { ミスが多くなり始める } \\
\text { 根気がなくなってくる }\end{array}$ & $\begin{array}{l}0.640 \\
0.585 \\
0.549 \\
0.526 \\
0.505\end{array}$ \\
\hline \multirow[b]{2}{*}{ 因 } & \multicolumn{2}{|c|}{ II 頭に表れる特徵 } & \multicolumn{2}{|c|}{ II ぼんやり感を表す特徵 } & \multicolumn{2}{|l|}{ II 自己責任外を表す特徵 } \\
\hline & 頭に表れる & 0.835 & $\begin{array}{l}\text { 頭がぼんやりする } \\
\text { ぼんやりする } \\
\text { 周囲がほやける }\end{array}$ & $\begin{array}{l}0.830 \\
0.697 \\
0.528\end{array}$ & $\begin{array}{l}\text { 思ったように動かないとイラつく } \\
\text { トラブルの発生で疲労度が増す } \\
\text { フリーズしたときにどっと疲れる } \\
\text { いらいらしてくる }\end{array}$ & $\begin{array}{l}0.691 \\
0.683 \\
0.679 \\
0.635\end{array}$ \\
\hline
\end{tabular}

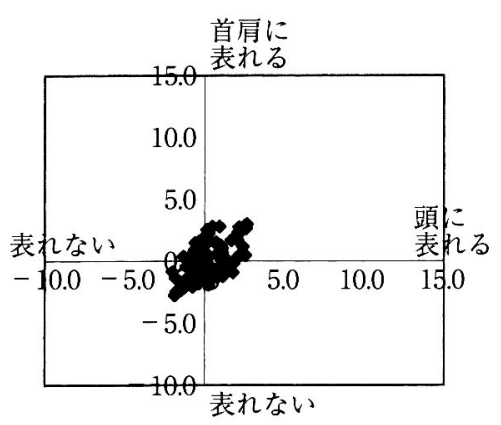

(a)（特定の）肉体部位に表れる疲労 (a) regional fatigue.

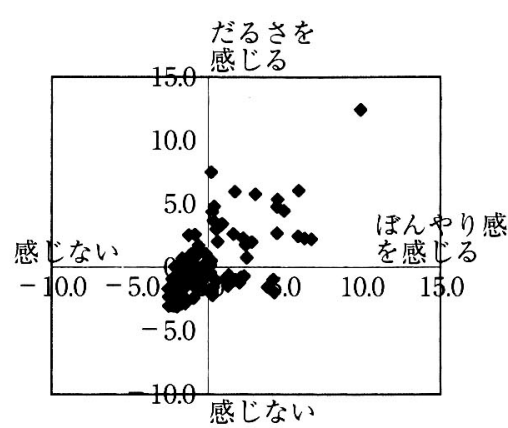

(b) 体全身に表れる疲労

(b) general fatigue.

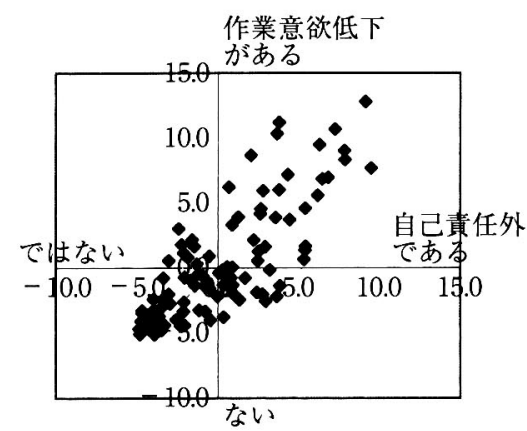

(c) 心的 (メンタル) に表れる疲労

(c) mental fatigue.

図 3 解析者全体の因子得点マップ

Fig. 3 Distribution map of factor mark.

まとまりにくいなど 25 項目に分け，あらゆる産業に利 用できる疲労調査法としてのチェックシートを推奨して いるＶVDT労働チェックマニュアルでは，VDT 作業 者の健康を守るための机や照明, 機器の環境（使いやす さや見やすさ）などに関するチェックシートを提供して いる. 計算機操作が多い職種への就業者を対象とした今 回の調査では, 納期, 品質, 性能などの要求を達成する ために必要な（時間，期間）進捗が逃避や焦りなどとな り疲労につながる傾向や思ったように動かないとイラつ く, トラブルの発生で疲労度が増す, といった自己責任 外の要因より疲労につながる傾向が示されている。これ らの傾向は，すでにある調査票からは拾えない内容を示 唆している。それぞれの職種の内部項目から特徵名の解 釈を行うと，下の内容があげられる。

・計算機操作全体の疲労の第 1 因子では “意欲の低下”, 第 2 因子では “焦燥感”，第 3 因子では “不安定感”, 第 4 因子では “自己責任外”，第 5 因子では “身体的 不調”.

- 職業別の営業販促職では “集中力の欠如”, 開発職で は “意欲興味の譶失”, 入力専門職では “倦点意識”,
事務職では “危機感危険感”.

・男女別では，男子が “(表現は間接的）作業意欲低 下”，女子が “(表現は直接的）作業能率低下”.

・就業者を，35 歳を層とした年齢層別では 35 歳以下に “切迫感と焦り”, 36 歳以上に“倦怠感の進行”.

調査した人員は少ないものの, 開発職（25名）内の 特徵の解釈では 36 歳以上（15 名）において全体的な疲 労感㧍よび (それからの) 逃避的感情が見られた。開発 職以外の 36 歳以上 (30 名) の特徵の解釈では疲労感扔 よび作業の行き詰まり感など類似した傾向があるもの の，逃避的感情は見られなかった．表 4 に示したよう に，開発職は計算機操作が多いのみならず，拘束時間全 体も長い。このことが 36 歳以上における逃避的感情の 発生に関係している可能性もあるが，開発職と開発職以 外の微妙な差異を見るには今回の調査人員は少なく，い わゆ3 35 歳定年説と年齢層ごとの疲労様態や疲労特徵 との関係を含め, 調査人員を増やして別途検討する必要 があると思われる。

詳細調査時に分けて記入させた設問（第一問から第三 問まで） 3 区分おのおのの抽出因子の内部項目による特 
徵名の解釈を行うと以下の内容があげられる.

・肉体部位に表れる疲労（疲労形容詞 6 項目）の第 1 因 子では“首肩に表れる”，第 2 因子では“頭に表れ る”.

- 体全身に表れる疲労（疲労形容詞 16 項目）の第 1 因 子では“だるさ感が表れる”，第 2 因子では“ぼんや り感が表れる”。

・心的（メンタルな）表れの疲労（疲労形容詞 29 項 目)”の第 1 因子では“作業意欲低下が表れる”，第 2 因子では“自己責任外の要因により表れる”。

（特定の）肉体部位に表れる疲労は, 表 5 の疲労全体 においても第 5 因子と下位である. 因子得点マップを見 ても図 3 (a)に示すように，解析対象者ごとに違うであろ う疲労の表れ方や程度を知るには不適と思われた。体全 身に表れる因子得点マップでは図 $3(\mathrm{~b})$ に示すように，0 近辺の得点者を除くと, それぞれの得点者ごとに違うプ ロットが示されており, 解析対象者ごとの疲労の表れ方 や程度を求めるには適していると思われた。 心的（メン タル）な因子得点マップでは図 3 (c)に示すように, 図の (a)(b)いずれとも違う傾向を示している。心的（メンタ ル）な疲労は, 表 6 の職種別ではすべての職種に表れて おり，バラバラな分布の表れが解析対象者ごとに違うで あろう疲労の表れ方や程度を知るには不適なのか, 非常 に有効なのか判断が難しい.

\section{8. おわりに}

本研究では, 職業としての計算機利用者向けの疲労調 查票を作成するための基礎資料を得ることを目的として いる. 計算機操作が多い職種への就業者を対象として, 計算機操作疲労に関する予備調查および詳細調査を行う ことにより, 計算機操作が及ぼすより具体的な疲労の特 徵を明らかにするべく検討を行った。

学生での実験例に基づく研究が多いなか, 対象者の条 件やばらつきは認められるものの, 実際の職業で計算機 操作を多く行っている人を対象とする重要性が改めて確 認され, 計算機操作疲労の具体的な特徵づけができたも のと思われる.内容としては以下があげられる.

・計算機操作疲労は, 長時間労働による心的（メンタ

ル）な疲労表現が多くみられる。

・自己責任外の要員で負担が発生し, 緊張が維持できな い状況に陥る。

- 職務遂行上の責任感, 集中力, 危機感が疲労により欠 けはじめる。

納期が迫っているから, くぎりが悪いから, 顧客の依
頼だからと仕事に熱中するあまりいつのまにか残業が重 なることも多い. 管理者が自らの経験則で残業を奨励す る雲囲気もあると聞く.その結果, 蓄積疲労から神経疲 労に至る ${ }^{3)}$ 可能性も秘めているであろう. 本研究により 得られた結果を基礎資料とし, 質問項目の取捨選択や, 取捨選択後の調査票を用いた調査を再度行い, 最終的に 計算機利用者向けの疲労調查票を作成することが必要と 思われる. 今後, 生理反応では認められにくい微細な疲 労の変化のような細やかな評価が可能な調査票となるよ う，さらに研究し，実用品を目指して行きたい．

最後になりましたが, 解析対象者, 所属企業の方々に 深く感謝申し上げます。

\section{参考文献}

1）厚生労働省政策統括官（労働担当）編：労働経済白書 (情報通信技術の革新と雇用), 至誠堂, 58〜 71, 2001.

2) 石田一宏：現代のストレスと神経疲労, 大月書店, 72〜 87, 2001.

3）墨岡 孝：テクノストレスからくる疲れをとる本, 中 央精版印刷, 122 148, 2001.

4）馬場快彦, 神代雅晴: OA 機器の健康対策, 日本経営協 会出版会, $224 \sim 245,1985$.

5）植村篤志, 村田厚生：事象関係電位から抽出された特 徵パラメータに基づく精神疲労評価の試み, 人間工学, 38(4), 187〜194, 2002.

6）鈴木まや, 平尾直靖, 寺下裕美, 小田弥生, 八木昭宏：一 過的な作業負荷によるストレス評価質問紙の項目と利用 方法の検討, 人間工学, 35(4), 259 267, 1999.

7）日本産業衛生学会, 産業疲労研究会編集委員会: 新装 産業疲労ハンドブック, 労働基準調査会, 362～363, 1995.

8）日本産業衛生学会, VDT 作業研究会:VDT労働 チェックマニュアル, 労働基準調査会, 129〜 187, 1993.

9）岩崎常人：3D ディスプレイを用いた視覚負荷による 眼精疲労, 人間工学, 38(1), 44〜 53, 2002.

10）人間工学教育研究会：人間工学入門, 日刊工業新聞社, 51〜66, 2001.

11） BFJ マンリー 原著者, 村上正康 訳他：多変量解析の 基礎, 培風館, 63〜 74, 1997.

12）浅野紀夫：統計・分析手法とデー夕の読み方, 日刊工 業新聞社, 175 201, 1996.

13）菅 民郎：多変量統計分析，現代数学社， 237～282, 2000.

14）西川向一, 長町三生：イメージスライドを用いた温熱 感覚の計測, 人間工学 33(1), 27〜34, 1997.

15）加藤麻樹：ホームヘルパーが必要とする福祉情報の共 分散構造に関する研究, 人間工学, 39(2), 65〜 75, 2003.

16）小林健三： $\mathrm{SE}$ の 35 歳の壁〜その乗り越え方〜, ソフ ト・リサーチ・センター, 34〜 42・133〜161, 2005.

17）松尾太加志, 中村知靖：誰も教えてくれなかった因子 分析, 北大路書房, 31 109, 2002. 